\title{
Quality characteristics and antioxidant activity of rice porridge supplemented with aronia (Aronia melanocarpa) powder
}

\author{
Eun-Sun Hwang* \\ School of Wellness Industry Convergence, Major in Food and Nutrition, Hankyong National University, \\ Anseong 17579, Korea
}

\section{아로니아 분말을 첨가하여 제조한 쌀죽의 품질 특성 및 항산화 활성}

\author{
황은선* \\ 한경대학교 웰니스산업융합학부 식품영양학 전공
}

\begin{abstract}
This study was conducted to investigate the quality and antioxidant characteristics of rice porridge supplemented with 3\%, 6\%, and 9\% Aronia melanocarpa (aronia) powder. The moisture content of the porridge was 80.41-80.84\%, and no significant difference was observed between the control and porridge supplemented with 3-9\% of aronia powder. The sugar content of the porridge increased, but $\mathrm{pH}$ and viscosity of the porridge decreased as the aronia content increased. Moreover, with respect to chromaticity determination, the $L^{*}$ and $b^{*}$ values decreased and the $a^{*}$ value increased as the aronia content increased. Of note, the total polyphenol, flavonoid, and anthocyanin contents also increased in the amount of aronia powder, compared to that in the control. The increase in the antioxidant activity measured by DPPH and ABTS radical scavenging activities and reducing power corresponded to the increase in the amount of aronia powder added as supplement. From the above results, the commercialization potential of the aronia-added porridge is considered to be positive. However, from the viewpoint of the astringency of aronia and the viscosity of the porridge, it is recommended that the content of aronia powder does not exceed $9 \%$ of the ratio of rice to maintain the quality of the porridge.
\end{abstract}

Key words : aronia, rice porridge, quality characteristics, anthocyanin, antioxidant activity

\section{서 론}

죽은 멥쌀, 찹쌀, 녹두, 조 등의 곡물을 주재료로 하여 물을 많이 붓고 끓여서 만든 반유동식으로 밥보다 더 오랜 역사를 지닌 것으로 알려져 왔다(Kim 등, 1998; Ko 등, 2016; Shim 등, 2020). 죽은 오랜 시간 끓이는 과정을 거치면서 알갱이가 잘 풀어져 소화가 쉽고 포만감이 커 한 끼 식사로 손색이 없 으며, 예로부터 보양식, 치료식, 노인식 그리고 이유식 등으 로 이용되어 왔다(Lee, 2013; Yoon과 Hawer, 2008). 죽은 물
의 첨가량에 따라 된죽, 묽은죽, 미음 등으로 분류하고 있으 며, 문헌에 나타난 죽의 종류는 약 200여 종이 보고되고 있다 (Lee 등, 2002). 최근에는 죽이 이유식, 노인식 또는 환자식이 라는 기존의 개념을 탈피하여 일반인들을 대상으로 하는 새 로운 식사 메뉴로의 변신을 하고 있으며, 죽 전문 프랜차이즈 가 등장하고, 다양한 즉석 죽을 상품으로 개발하여 판매하고 있다(Kim 등, 2017). 건강에 대한 소비자들의 관심이 증가함 에 따라 죽의 제조에서도 기존의 조리법을 기본으로 하여 생 리활성 성분이 풍부하다고 알려진 단호박, 고구마, 마, 뽕잎,

*Corresponding author. E-mail : ehwang@hknu.ac.kr, Phone : +82-31-670-5182, Fax : +82-31-670-5189

Received 07 September 2020; Revised 23 October 2020; Accepted 23 November 2020.

Copyright (c) The Korean Society of Food Preservation.

This is an Open Access article distributed under the terms of the Creative Commons Attribution Non-Commercial License (http://creativecommons.org/licenses/by-nc/4.0) which permits unrestricted non-commercial use, distribution, and reproduction in any medium, provided the original work is properly cited. 
오디, 느타리버섯, 닭, 북어 등의 부재료를 첨가하여 영양 및 기능적인 효과와 관능적인 특성을 동시에 만족시키려는 연구 가 진행되고 있다(Kim and Kwak, 2011; Kim과 Kim, 2007; Kim 등, 2017; Shim 등, 2020).

아로니아(Aronia melanocarpa)는 북아메리카가 원산지인 장미과에 속하는 관목으로 중세 유럽의 왕족들이 즐겨 먹어 서 킹스 베리(King's berry), 또는 짙은 자주색을 띠고 입안에 넣었을 때, 쓰고 시큼하고 건조한 느낌(mouth-drying feeling) 때문에 블랙초크베리(black chokeberry)라고도 불린다(Kulling 등, 2008). 아로니아는 다른 작물에 비해 토양 적응성이 우수 하고 재배가 쉬워 20세기 중반 이후부터 유럽 전역으로 확산 되었고, 우리나라에는 10 여 년 전에 도입되어 충북, 전북을 비롯한 국내 전 지역에서 재배되고 있다(Jeon 등, 2018; Kokotkiewicz 등, 2010).

아로니아에는 다른 베리류에 비해 질병을 예방하는 phenolic acids, anthocyanins, flavonids, proanthocyanidins 등의 생리활성물질이 풍부하여 세포주 실험과 동물 실험으로 건강 기능성이 입증되었다(Wu 등, 2004). 아로니아는 대장암 및 유방암 세포의 성장을 억제하고, 염증반응을 감소시키고, 혈 당을 낮추고, 인슐린 저항성을 개선하여 당뇨의 예방과 치료 에 효과적이고, 조직을 이환시켜 혈류의 흐름을 좋게 하고, 관 상동맥 내부에 혈전이 생성되는 것을 억제하고 혈압을 낮추어 각종 혈관질환을 예방하는 것으로 알려져 있다(Banjari 등, 2017; Kulling 등, 2008; Yamane 등, 2017; Sidor 등, 2019). 아로니아에는 안토시아닌을 비롯하여 폴리페놀, 플라보노 이드 등의 항산화 성분이 풍부하지만, 단단한 조직감과 시큼 하고 떫은맛을 지니고 있어 소비자들이 쉽게 생과로 섭취하 기에는 어려움이 있다. 따라서 외국에서는 아로니아를 착즙 액이나 농축액으로 제조한 후에 다른 과실류와 혼합하여 주 스를 제조하거나, 천연색소 및 의약품의 원료로 이용하고 있 다(Sidor 등, 2019; Tsuda, 2012). 국내에서도 아로니아를 첨 가한 설기떡, 스펀지케이크, 머핀, 쿠키, 잼 등 다양한 제품들 이 개발되고 있다(Hwang과 Hwang, 2015; Hwang과 Tai, 2014; Jang 등, 2018; Lee와 Choi, 2016; Park과 Chung, 2014).
현재까지 다양한 기능성 재료를 첨가하여 제조한 죽의 품 질 특성에 관한 연구는 진행되어 왔으나, 아로니아를 첨가하 여 제조한 죽에 대한 연구는 거의 이루어지지 않았다. 본 연 구는 항산화 성분이 풍부한 아로니아 분말을 첨가하여 죽을 제조하여 이화학적 품질과 항산화 특성을 조사하였다.

\section{재료 및 방법}

\section{실험재료 및 시약}

본 연구에 사용한 아로니아(Aronia melanocarpa, black chokeberry)는 경기도 일산의 아로니아 재배 농가에서 2019 년 8월에 수확한 것을 구입하여 냉동 보관하면서 사용하였다. 멥쌀은 경기도 이천시 모가면에서 수확한 쌀을 농협에서 구매 하였고, 소금(Sajo Haepyo, Incheon, Korea)은 시판품을 구매 하여 실험에 사용하였다. Folin-Ciocalteu's phenol reagent, 1,1'-diphenyl-2-picrylhydrazyl(DPPH), gallic acid, catechin 과 sodium phosphate monobasic은 Sigma-Aldrich Chemical Co.(St. Louis, MO, USA), 2,2'-azino-bis(3-ethylbenzothiazoline-6-sulfonic acid) diammonium salt(ABTS)는 Fluk(Heidelberg, Germany)에서 구입하였다. 그 외 품질 및 항산화 활 성을 측정하기 위해 사용한 시약들은 Sigma-Ardrich Chemical Co.와 Juncei Chemical Co., Ltd.(Tokyo, Japan)에서 구입하 여 사용하였다.

\section{아로니아 분말 및 죽 제조}

아로니아는 흐르는 물에서 깨끗이 세척한 후 물기를 제거 하여 세척한 아로니아를 $-80^{\circ} \mathrm{C}$ 에서 동결시킨 후에 동결건조기 (FDU-1200, EYELA, Tokyo, Japan)을 이용하여 건조하였다. 동결건조된 아로니아를 블랜더(Hanil, Seoul, Korea)에 넣어 고속에서 3 분간 3 회에 걸쳐 곱게 마쇄하여 분말을 얻었다.

수차례 예비실험을 거쳐 죽을 제조하고 예비 관능평가를 실시한 결과, 맛과 점도 등을 고려할 때 아로니아 분말을 쌀 중량의 최대 $9 \%$ 까지 첨가하는 것이 적절한 것으로 결정하였 다. 예비실험 결과에 따라 Table 1과 같은 비율로 죽을 제조

Table 1. Formula for rice porridge containing different contents of aronia powder

\begin{tabular}{crrrr}
\hline \multirow{2}{*}{ Ingredient } & \multicolumn{5}{c}{${\text { Aronia powder }(\%)^{1)}}^{1}$} \\
\cline { 2 - 5 } & 0 & \multicolumn{1}{c}{6} & \multicolumn{1}{c}{6} \\
\hline Rice $(\mathrm{g})$ & 200 & 194 & 188 & 182 \\
Aronia powder $(\mathrm{g})$ & 0 & 6 & 12 & 18 \\
Water $(\mathrm{mL})$ & 800 & 800 & 800 & 800 \\
Salt $(\mathrm{g})$ & 2 & 2 & 2 & 2 \\
\hline
\end{tabular}

\footnotetext{
${ }^{1)}$ Aronia powder $(3,6$ and $9 \%$ ) was added based on the total weight of porridge.
} 
하였다. 멥쌀을 5 회 씻어 30 분 동안 수침한 다음 체에 받쳐 30 분 동안 물기를 뺀 다음에 믹서기에 넣고 20초 동안 분쇄 하였다. 분쇄한 멥쌀가루에 아로니아 분말을 혼합한 후에 물 을 넣고 끓기 시작하면 약불에서 2 분간 충분히 호화시킨 후 에 중불에서 3 분, 마지막에 약불에서 2 분간 끓여서 죽을 완성 하였다. 완성된 죽은 실온에서 30 분 동안 식힌 후 각종 분석 의 시료로 사용하였다.

\section{일반성분 분석}

본 실험에서 제조한 죽의 일반성분분석은 $\mathrm{AOAC}(1995)$ 의 방법에 따라 측정하였다. 수분 함량은 상압건조방법으로 $105^{\circ} \mathrm{C}$ 에서 건조하여 정량하였고, 조회분은 $600^{\circ} \mathrm{C}$ 직접회화법으로 측정하였다. 조단백질 함량은 semimicro-Kjeldhl법으로 자동 단백질 분석기(Kjeltec 2400 AUT, Foss Tecator, Eden Prairie, MN, USA)로 분석하였고, 조지방은 Soxhlet 추출기 (Soxtec System HT 1043, Foss Tecator, Eden Prairie, MN, USA)를 사용하여 diethyl ether로 추출하여 정량하였다.

\section{$\mathrm{pH}$, 당도 및 점도 측정}

$\mathrm{pH}$ 는 시료 $5 \mathrm{~g}$ 에 10 배의 증류수를 넣고, 초음파를 이용하 여 5 분 동안 균질화한 후에 $13,500 \times g$ 에서 10 분간 원심분리 (Mega 17R, Hanil Co., Incheon, Korea) 하였다. 원심분리한 시료의 상등액을 취하여 $\mathrm{pH}$ meter(420 Benchtop, Orion Research, Beverly, MA, USA)로 $\mathrm{pH}$ 를 측정하였다.

당도는 제조한 시료에 2 배의 증류수를 넣어 희석하고 초음 파를 이용하여 5 분 동안 균질화하고 $13,500 \times g$ 에서 10 분간 원심분리한 후, 상등액을 취하여 당도계(PR-201 $\alpha$, Atago Co., Tokyo, Japan)로 측정하였다.

점도는 점도계(Brookfield DV3T, Brookfield AMETEK, Inc., Middleboro, MA, USA)를 사용하여 측정하였다. 시료 $150 \mathrm{~g}$ 을 용기에 취해 spindle No. 9을 $20 \mathrm{rpm}$ 의 회전속도로 맞추어 10 초 간격으로 2 분간 작동시켜 측정하였다.

\section{Hunter 색도 측정}

색도는 시료를 지름 $50 \mathrm{~mm}$ 의 투명 용기에 넣고 색차계 (Chrome Meter CR-300, Minolta, Tokyo, Japan)를 사용하여 명도(L, lightness), 적색도(a, redness), 황색도(b, yellowness) 를 측정하였다. 표준색은 $\mathrm{L}^{*}, \mathrm{a}^{*}, \mathrm{~b}^{*}$ 값이 각각 $97.10,+0.24$, +1.75 인 백색 표준판을 사용하였다.

\section{총폴리페놀, 총플라보노이드 및 총안토시아닌 함량 분석}

총폴리페놀과 플라보노이드 함량을 측정하기 위해 시료 3 $\mathrm{g}$ 에 4 배의 증류수를 넣고 $40^{\circ} \mathrm{C}$ 에서 5 분 동안 초음파 처리를 한 후에 $13,500 \times g$ 에서 10 분간 원심분리(Mega 17R, Hanil Co.)하여 상층액을 얻어 죽 추출물로 하였다.
총폴리페놀 함량은 적절한 농도로 희석한 죽 추출물 $(0.5$ $\mathrm{mL}$ )에 $2 \mathrm{~N}$ Folin 시약 $0.5 \mathrm{~mL}$ 를 혼합한 뒤 3 분간 실온에서 반응시킨 후, $2 \% \mathrm{Na}_{3} \mathrm{CO}_{3} 1.5 \mathrm{~mL}$ 를 첨가한 뒤 2시간 동안 암소에서 반응시켰다. 반응물은 microplate reader(Infinite M200 Pro, Tecan Group Ltd., San Jose, CA, USA)를 이용하 여 $760 \mathrm{~nm}$ 에서 흡광도를 측정하였다. 죽에 함유된 총폴리페 놀 함량은 gallic acid의 표준곡선 $(6.25-100 \mu \mathrm{g} / \mathrm{mL})$ 을 이용하 여 죽 g당 gallic acid equivalent(GAE)로 표시하였다.

총플라보노이드 함량은 적절한 농도로 희석한 죽 추출물 $1 \mathrm{~mL}$ 와 $2 \%$ aluminium chloride methanolic solution $1 \mathrm{~mL}$ 를 혼합하여 실온에서 15 분 동안 반응시켰다. 반응물은 $430 \mathrm{~nm}$ 에서 흡광도를 측정하였다. 죽에 함유된 총플라보노이드 함 량은 quercetin의 표준곡선 $(6.25-100 \mu \mathrm{g} / \mathrm{mL})$ 을 이용하여 죽 $\mathrm{g}$ 당 quercetin equivalent $(\mathrm{QE})$ 로 나타내었다.

총안토시아닌 함량은 적절한 농도로 희석한 죽 추출물 $100 \mu \mathrm{L}$ 에 $\mathrm{pH} 1$ 완충용액 $1,900 \mu \mathrm{L}$ 와 $\mathrm{pH} 4.5$ 완충용액 1,900 $\mu \mathrm{L}$ 를 각각 첨가하여 혼합한 후, $520 \mathrm{~nm}$ 와 $700 \mathrm{~nm}$ 에서 흡광 도를 측정하고, 아래 식에 따라 계산하였다(Lee 등, 2005).

Anthocyanin content $(\mathrm{mg} / 100 \mathrm{~g})$

$$
=(\mathrm{A} \times \mathrm{MW} \times \mathrm{DF} \times 1 \times 1,000) /(\varepsilon \times 1)
$$

$\mathrm{A}=\left(\mathrm{OD}_{520 \mathrm{~nm}}-\mathrm{OD}_{700 \mathrm{~nm}}\right)$ of $\mathrm{pH} 1.0-\left(\mathrm{OD}_{520 \mathrm{~nm}}-\mathrm{OD}_{700 \mathrm{~nm}}\right)$ of $\mathrm{pH} 4.5$

MW (molecular weight of cyanidin-3-glucoside) $=449.2$

DF (dilution factor)

$\varepsilon$ (cyanidin-3-glucoside molar absorptivity) $=26,900$

$1=$ total volume $(1 \mathrm{~mL})$

\section{$\mathrm{DPPH}$ 라디칼 소거능 측정}

아로니아 죽의 DPPH 라디칼 소거능은 Cheung 등(2003) 의 방법으로 측정하였다. 적절한 농도로 희석한 죽 추출물 $100 \mu \mathrm{L}$ 를 96-well plate에 넣고 $0.2 \mathrm{mM} \mathrm{DPPH}$ 용액 $100 \mu \mathrm{L}$ 를 첨가한 후 $37^{\circ} \mathrm{C}$ 에서 30 분간 반응시켰다. Microplate reader를 사용하여 $515 \mathrm{~nm}$ 에서 흡광도를 측정하였다. 죽의 $\mathrm{DPPH}$ 라디칼 소거활성은 아래 식에 측정된 흡광도 값을 대 입하여 산출하였다.

$$
\begin{aligned}
& \mathrm{DPPH} \text { 라디칼 소거능 }(\%) \\
& \quad=(1-\text { 시료첨가구의 흡광도/대조구의 흡광도 }) \times 100
\end{aligned}
$$

\section{ABTS 라디칼 소거능 측정}

아로니아 죽의 ABTS 라디칼 소거능은 Re 등(1999)의 방 법으로 측정하였다. $7.0 \mathrm{mM} \mathrm{ABTS}$ 와 $2.45 \mathrm{mM}$ potassium persulfate를 실험 24시간 전에 암소에서 반응시켜 ABTS 양 이온을 형성시킨 후 $735 \mathrm{~nm}$ 에서 흡광도 값이 $0.17 \pm 0.03$ 이 
되도록 에탄올로 희석하여 사용하였다. 적절한 농도로 희석 한 죽 추출물 $100 \mu \mathrm{L}$ 를 96-well plate에 넣고 흡광도를 맞춘 $\mathrm{ABTS}$ 용액 $100 \mu \mathrm{L}$ 를 첨가한 후 $37^{\circ} \mathrm{C}$ 에서 30 분간 반응시켰 다. Microplate reader를 사용하여 $732 \mathrm{~nm}$ 에서 흡광도를 측 정하였다. 죽의 $\mathrm{ABTS}$ 라디칼 소거활성은 아래 식에 측정된 흡광도 값을 대입하여 산출하였다.

$$
\begin{aligned}
& \text { ABTS 라디칼 소거능 }(\%) \\
& =(1-\text { 시료첨가구의 흡광도 / 시료 무 첨가구의 흡광도 }) \\
& \quad \times 100
\end{aligned}
$$

\section{환원력 측정}

아로니아 죽의 환원력은 Oyaizu(1986) 방법으로 측정하였 다. 적절한 농도로 희석한 시료 추출물 $1 \mathrm{~mL}$ 에 인산 완충액 (200 mM, pH 6.6) 및 $1 \%$ 의 potassium ferricyanide $1 \mathrm{~mL}$ 를 차례로 가한 다음 $50^{\circ} \mathrm{C}$ 의 수욕상에서 20 분간 반응시켰다. 여 기에 $10 \% \mathrm{TCA}$ 용액을 $1 \mathrm{~mL}$ 가하여 $13,500 \times g$ 에서 15 분간 원심분리한 후 얻은 상등액 $1 \mathrm{~mL}$ 에 증류수 및 ferric chloride 를 각각 $1 \mathrm{~mL}$ 씩 가하여 혼합한 후 $720 \mathrm{~nm}$ 에서 흡광도를 측 정하였다.

\section{통계분석}

모든 결과는 3회 반복실험에 대한 평균(mean) \pm 표준편차 (SD)로 나타내었다. 실험결과에 대한 통계처리는 SPSS software package(Version 17.0, SPSS Inc., Chicago, IL, USA)를 이용하여 평균과 표준편차로 나타내었고, 각 처리군 간의 유 의성에 대한 검증은 $\mathrm{ANOVA}$ 를 이용하여 유의성을 확인한 후, $\mathrm{p}<0.05$ 수준에서 Duncan's multiple range test를 이용하 여 분석하였다.

\section{결과 및 고찰}

\section{일반성분 함량}

아로니아 분말 함량을 달리하여 제조한 죽의 수분, 회분
및 조단백질 측정 결과는 Table 2 와 같다. 아로니아 죽의 수 분 함량은 80.41-80.84\%로 대조군과 아로니아 분말을 3-9\% 까지 첨가하여 제조한 죽에서 유의적인 차이가 관찰되지 않 았다. 회분 함량은 아로니아 분말을 첨가하지 않은 대조군에 서는 $0.15 \%$ 였고, 아로니아 분말 함량이 $3-6 \%$ 까지 증가함에 따라 0.14-0.15\%로 대조군과 비교할 때 유의적인 차이가 없었 다. 아로니아 분말을 $9 \%$ 첨가하여 제조한 죽의 회분은 $0.24 \%$ 로 가장 높게 나타났다. 조단백질은 아로니아 분말을 첨가하 지 않고 제조한 대조군에서 $0.34 \%$ 로 가장 높았고, 아로니아 분말을 첨가하여 제조한 죽에서는 $0.21-0.23 \%$ 로 대조군에 대해 낮게 나타났으나, 아로니아 분말 함량에 따른 차이는 없 는 것으로 나타났다. 죽은 다량의 물을 넣고 약한 불에서 장 시간 호화시켜 만들기 때문에 밥에 비해 수분함량이 높다 (Lee 등, 2002). 선행연구에 따르면 죽의 수분함량은 사용하 는 부재료, 가열시간, 호화 정도, 퍼짐성 등에 따라 차이가 있 고, 대략 74.3-87.5\%의 수분을 지니는 것으로 보고(Jung 등, 2020; Lee 등, 2004)하고 있어 본 연구결과와 유사한 경향을 나타냈다.

\section{$\mathrm{pH}$, 당도 및 점도 측정}

아로니아 분말 함량을 달리하여 제조한 죽의 $\mathrm{pH}$, 당도 및 점도의 측정결과는 Table 3 과 같다. 아로니아 분말 첨가량을 달리하여 제조한 죽의 $\mathrm{pH}$ 는 아로니아 함량이 증가함에 따라 감소하는 경향을 보였다. 즉, 아로니아 분말을 첨가하지 않고 제조한 죽의 $\mathrm{pH}$ 는 5.77 로 가장 높았고, 아로니아 분말을 $3-9 \%$ 까지 증가시킴에 따라 제조한 죽의 $\mathrm{pH}$ 는 5.72에서 4.98 까지 감소하였다. 아로니아 생과의 $\mathrm{pH}$ 는 3.86-4.06으로 재배 지역 및 품종에 따라 차이가 있으며, malic acid, citric acid, quinic acid, isocitric acid와 같은 유기산이 포함되어 있다 (Jeon 등, 2018; Snebergrova 등, 2014). 아로니아 분말 함량 이 증가함에 따라 나타난 $\mathrm{pH}$ 감소 현상은 멥쌀에 비해 아로 니아의 $\mathrm{pH}$ 가 낮기 때문이며, 선행연구에서도 아로니아를 첨 가하여 제조한 쿠키, 양갱, 설기떡의 $\mathrm{pH}$ 는 아로니아 첨가량 이 증가함에 따라 $\mathrm{pH}$ 가 감소하는 것으로 보고하여 본 연구결

Table 2. Proximate analysis of rice porridge containing different contents of aronia powder

\begin{tabular}{ccccc}
\hline & \multicolumn{5}{c}{ Aronia powder (\%) } \\
\cline { 2 - 5 } Measurement (\%) & 0 & 3 & 6 & 9 \\
\hline Moisture & $80.41 \pm 1.09^{1) \mathrm{a} 2)}$ & $80.54 \pm 0.34^{\mathrm{a}}$ & $80.60 \pm 0.24^{\mathrm{a}}$ & $80.84 \pm 0.41^{\mathrm{a}}$ \\
Ash & $0.15 \pm 0.01^{\mathrm{b}}$ & $0.14 \pm 0.02^{\mathrm{b}}$ & $0.15 \pm 0.00^{\mathrm{b}}$ & $0.24 \pm 0.03^{\mathrm{a}}$ \\
Crude protein & $0.34 \pm 0.06^{\mathrm{a}}$ & $0.23 \pm 0.03^{\mathrm{b}}$ & $0.22 \pm 0.00^{\mathrm{b}}$ & $0.21 \pm 0.04^{\mathrm{b}}$ \\
\hline
\end{tabular}

\footnotetext{
${ }^{1)}$ Data were the mean $\pm \mathrm{SD}$ of triplicate experiment.

${ }^{2) a, b}$ Means with the same superscript within the same row are not significantly different at $\mathrm{p}<0.05$.
} 
Table 3. Sugar contents, $\mathrm{pH}$, and viscosity of rice porridge containing different contents of aronia powder

\begin{tabular}{ccccc}
\hline & \multicolumn{4}{c}{ Aronia powder (\%) } \\
\cline { 2 - 5 } Measurement (\%) & 0 & 3 & 6 & 9 \\
\hline $\mathrm{pH}$ & $5.77 \pm 0.00^{1) \mathrm{a} 2)}$ & $5.72 \pm 0.00^{\mathrm{b}}$ & $5.37 \pm 0.00^{\mathrm{c}}$ & $4.98 \pm 0.00^{\mathrm{d}}$ \\
Sugar contents ( ${ }^{\circ}$ Brix) & $3.56 \pm 0.05^{\mathrm{b}}$ & $3.53 \pm 0.05^{\mathrm{b}}$ & $3.60 \pm 0.00^{\mathrm{b}}$ & $3.80 \pm 0.00^{\mathrm{a}}$ \\
Viscosity (cP) & $3,502 \pm 27^{\mathrm{a}}$ & $3,247 \pm 24^{\mathrm{b}}$ & $2,429 \pm 19^{\mathrm{c}}$ & $2,100 \pm 15^{\mathrm{d}}$ \\
\hline
\end{tabular}

${ }^{1)}$ Data were the mean \pm SD of triplicate experiments.

${ }^{2) a-d}$ Means with the same superscript within the same row are not significantly different at $\mathrm{p}<0.05$.

과와 유사한 경향을 보였다(Hwang과 Hwang, 2015; Hwang 과 Tai, 2014; Lee와 Choi, 2016).

아로니아 분말을 첨가하지 않고 제조한 죽의 당도는 3.56 ${ }^{\circ} \mathrm{Brix}$ 로 나타났고, 아로니아 분말을 3\% 및 $6 \%$ 첨가하여 제조 한 죽의 당도는 3.53 및 $3.60{ }^{\circ} \mathrm{Brix}$ 로 통계적으로 유의적인 차 이를 나타내지 않았다. 아로니아 분말을 $9 \%$ 첨가하여 제조한 죽의 당도는 $3.80{ }^{\circ} \mathrm{Brix}$ 로 가장 높게 나타났다. 아로니아에는 sucrose, fructose, sorbitol과 같은 당이 함유되어 있어 있는 것 으로 보고되고 있으며(Bolling 등, 2015; D'Alessandro 등, 2013), 이에 따라 죽에 첨가하는 아로니아 함량이 증가함에 따라 당도도 높아진 것으로 사료된다.

아로니아 분말 함량을 달리하여 제조한 죽의 점도 측정 결과는 Table 3 과 같다. 아로니아를 첨가하지 않은 대조군의 점도가 3,502 centipoise $(\mathrm{cP})$ 로 가장 높았고, 아로니아 첨가 량이 $3 \%$ 인 죽에서는 $3,247 \mathrm{cP}$, 아로니아 분말 함량이 $6 \%$ 및 $9 \%$ 인 죽에서는 2,429 및 $2,100 \mathrm{cP}$ 로 감소하였다. 쌀 전분 은 아밀로오스와 아밀로펙틴으로 구성되어 아로니아에 비해 점성이 높기 때문에 쌀 대신 아로니아 첨가량이 증가함에 따 라 죽의 점성이 감소한 것으로 사료된다. 죽의 점성은 아밀 로오스 함량과 밀접한 관련성이 있고, 가열에 의해 전분 입 자의 세포벽이 파괴되면 아밀로오스가 용해되어 점도가 증 가하고, 용해성 저분자 물질, 단백질, 회분 등의 용출물도 점 도에 영향을 주는 것으로 알려져 있다( $\operatorname{Sim}$ 등 2018).

\section{색도 측정}

아로니아 분말 첨가 죽의 색도 측정 결과는 Table 4 와 같 다. 죽의 밝은 정도를 나타내는 $\mathrm{L} *$ 값은 아로니아 분말을 첨 가하지 않은 대조군이 53.01로 가장 높게 나타났으며, 아로 니아 분말 첨가량이 증가함에 따라 감소하는 경향을 보였으 며, 아로니아 분말 $9 \%$ 첨가군에서 37.26 으로 가장 낮은 명도 값을 나타냈다. 적색도를 나타내는 $\mathrm{a}$ *값은 아로니아 분말을 첨가하지 않은 죽에서는 -0.87 로 가장 낮은 값을 나타냈고, 아로니아 분말 첨가량이 3-9\%로 증가함에 따라 a*값도 5.30 에서 5.93으로 증가하였다. 황색도를 나타내는 $b^{*}$ 값은 아로 니아 분말을 첨가하지 않고 제조한 대조군에서 0.54 로 가장 높았고, 아로니아 분말 첨가량이 증가함에 따라 감소하였다.

식품 제조 시 첨가하는 재료 및 부재료에 의해 식품의 색 이 달라진다. 아로니아 분말 첨가량이 증가할수록 명도가 감 소하고 적색도가 증가하는 것은 흰색의 멥쌀에 비해 아로니 아 특유의 짙은 적색 때문으로, 아로니아를 첨가하여 제조한 스펀지케이크, 설기떡, 쿠키, 머핀에서도 아로니아 분말 첨가 량이 증가함에 따라 명도와 황색도는 감소하고, 적색도는 증 가함을 확인하였다(Hwang과 Hwang, 2015; Jang 등, 2018; Lee와 Choi, 2016; Park과 Chung, 2014).

\section{총폴리페놀, 총플라보노이드 및 총안토시아닌 함량 분석}

아로니아 첨가 죽의 총폴리페놀 및 총플라보노이드 함량 분석결과는 Table 5 와 같다. 죽 제조시 아로니아 분말 첨가량

Table 4. Changes in Hunter's color values of rice porridge containing different contents of aronia powder

\begin{tabular}{ccccc}
\hline \multirow{2}{*}{ Parameters } & \multicolumn{4}{c}{ Aronia powder (\%) } \\
\cline { 2 - 5 } & 0 & 3 & 6 & 9 \\
\hline L & $53.01 \pm 0.24^{1) \mathrm{a} 2)}$ & $42.31 \pm 0.34^{\mathrm{b}}$ & $38.86 \pm 0.70^{\mathrm{c}}$ & $37.26 \pm 0.23^{\mathrm{d}}$ \\
a & $-0.87 \pm 0.05^{\mathrm{c}}$ & $5.30 \pm 0.09^{\mathrm{b}}$ & $5.31 \pm 0.15^{\mathrm{b}}$ & $5.93 \pm 0.06^{\mathrm{a}}$ \\
b & $0.54 \pm 0.04^{\mathrm{a}}$ & $0.34 \pm 0.08^{\mathrm{b}}$ & $0.12 \pm 0.04^{\mathrm{c}}$ & $0.11 \pm 0.03^{\mathrm{c}}$ \\
\hline
\end{tabular}

\footnotetext{
${ }^{1)}$ Data were the mean \pm SD of triplicate experiments.

${ }^{2) \mathrm{a}-\mathrm{d}}$ Means with the different superscript within the same row are significantly different at $\mathrm{p}<0.05$.
} 
Table 5. Total polyphenolics, total flavonoid, and total anthocyanin contents of rice porridge containing different contents of aronia powder

\begin{tabular}{ccccc}
\hline Contents & \multicolumn{3}{c}{ Aronia powder (\%) } \\
\cline { 2 - 5 } & 0 & 3 & 6 & 9 \\
\hline Total polyphenol $\left(\mathrm{mg} \mathrm{GAE}^{1 / 1} / \mathrm{g}\right)$ & $3.77 \pm 0.17^{4) \mathrm{d} 5)}$ & $14.49 \pm 0.23^{\mathrm{c}}$ & $26.21 \pm 0.13^{\mathrm{b}}$ & $36.88 \pm 0.40^{\mathrm{a}}$ \\
Total flavonoid $\left(\mathrm{mg} \mathrm{QE}^{2} / \mathrm{g}\right)$ & $7.57 \pm 0.48^{\mathrm{c}}$ & $11.17 \pm 0.40^{\mathrm{c}}$ & $16.42 \pm 0.62^{\mathrm{b}}$ & $24.88 \pm 5.56^{\mathrm{a}}$ \\
Total anthocyanin $\left(\mathrm{mg} \mathrm{C}^{\mathrm{a}} \mathrm{G}^{3)} / \mathrm{g}\right)$ & $0.00 \pm 0.00^{\mathrm{d}}$ & $0.05 \pm 0.01^{\mathrm{c}}$ & $0.16 \pm 0.04^{\mathrm{b}}$ & $0.43 \pm 0.07^{\mathrm{a}}$ \\
\hline
\end{tabular}

${ }^{1)} \mathrm{GAE}$, gallic acid equivalent.

${ }^{2)} \mathrm{QE}$, quercetin equivalent.

${ }^{3)} \mathrm{C} 3 \mathrm{G}$, cyanidin-3-glucoside equivalent.

${ }^{4)}$ Data were the mean $\pm \mathrm{SD}$ of triplicate experiments.

${ }^{5) a-d}$ Values with the different superscript within the same row are significantly different at $\mathrm{p}<0.05$.

이 증가함에 따라 아로니아에 함유된 총페놀화합물 함량도 증가하였다. 아로니아 분말을 첨가하지 않고 제조한 죽의 총 폴리페놀 함량은 중량 $1 \mathrm{~g}$ 당 gallic acid를 기준으로 $3.77 \mathrm{mg}$ 이었으나, 아로니아 첨가량에 비례하여 죽에 함유된 총폴리 페놀 함량이 증가하였다. 즉, 아로니아 분말을 $3 \%, 6 \%$ 및 $9 \%$ 첨가한 죽에서 총폴리페놀 함량은 각각 $14.49,26.21$ 및 $36.88 \mathrm{mg}$ 으로 이는 아로니아를 첨가하지 않은 죽에 비해 총 폴리페놀 함량이 3.84-9.78배까지 증가하였다. 아로니아를 첨가하지 않고 제조한 죽의 총플라보노이드 함량은 중량 1 $\mathrm{g}$ 당 quercetin을 기준으로 $7.57 \mathrm{mg}$ 이었고, 아로니아 분말 첨 가량에 비례하여 죽에 함유된 총플라보노이드 함량도 증가함 을 확인하였다. 즉, 아로니아를 $3 \%, 6 \%$ 및 $9 \%$ 첨가한 죽의 총플라보노이드 함량은 각각 $11.17 \mathrm{mg}, 16.42 \mathrm{mg}$ 및 24.88 $\mathrm{mg}$ 으로 확인되었다. 이는 아로니아 분말을 첨가하지 않은 죽 에 비해 총플라보노이드 함량이 1.48-3.29 배까지 증가한 수 치였다. 총안토시아닌 함량을 측정한 결과, 대조군에서는 안 토시아닌이 검출되지 않았고, 아로니아 분말을 3-9\%까지 첨 가함에 따라 cyanidin-3-glucoside를 기준으로 시료 $1 \mathrm{~g}$ 을 기 준으로 $0.05-0.43 \mathrm{mg}$ 까지 증가하였다.

아로니아에 함유된 폴리페놀 성분을 HPLC로 분석한 결 과, 아로니아에는 chlorogenic acid, neochlorogenic acid, ferulic acid, catechin, epicatechin, $p$-coumaric acid, caffeic acid 등을 확인하였다(Denev 등, 2012; Gim 등, 2020). 아로 니아에는 cyanidin-3-O-glucoside, cyanidin-3-O-galactoside, cyanidin-3-O-arabinoside, cyanidin-3-O-xyloside와 같은 안 토시아닌 성분을 함유하고 있다(Hwang과 Thi, 2016). 선행 연구에서 아로니아 동결건조 분말 $1 \mathrm{~g}$ 에 함유되어 있는 총폴 리페놀은 gallic acid를 기준으로 276.73-412.11 mg, 총플라 보노이드는 catechin을 기준으로 171.75-234.87 mg 함유되어 있었다. 총안토시아닌은 동결건조 분말 $100 \mathrm{~g}$ 당 cyanidin-3glucoside 기준으로 13.75-16.48 mg으로 확인하였다(Hwang 과 Thi, 2016).

\section{항산화 활성 측정}

아로니아 분말을 첨가하여 제조한 죽의 항산화 활성을 측 정한 결과는 Table 6에 나타내었다. DPPH 라디칼 소거능은 아로니아를 첨가하지 않은 대조군에서 $2.57 \%$ 로 나타났고, 아로니아 분말을 3-9\%까지 첨가한 죽에서는 $\mathrm{DPPH}$ 라디칼 소거능이 각각 26.46-62.77\%까지 증가하였고, 이는 아로니 아 분말을 첨가하지 않은 죽에 비해 $\mathrm{DPPH}$ 라디칼 소거능이 10.30-24.42배까지 증가한 수치였다. 아로니아 분말 첨가량 에 비례하여 ABTS 라디칼 소거능도 높아지는 경향을 보였 다. 아로니아 분말을 첨가하지 않은 죽의 ABTS 라디칼 소거 능은 측정할 수 없었으나, 아로니아 분말을 3-9\%까지 첨가하

Table 6. Antioxidant activities of rice porridge containing different contents of aronia powder

\begin{tabular}{ccccc}
\hline \multirow{2}{*}{ Activities } & \multicolumn{4}{c}{ Aronia powder (\%) } \\
\cline { 2 - 5 } & 0 & 3 & 6 & 9 \\
\hline DPPH radical scavenging (\%) & $2.57 \pm 1.04^{1) \mathrm{d} 2)}$ & $26.46 \pm 1.20^{\mathrm{c}}$ & $43.02 \pm 0.78^{\mathrm{b}}$ & $62.77 \pm 0.88^{\mathrm{a}}$ \\
ABTS radical scavenging (\%) & $\mathrm{ND}^{3)}$ & $2.69 \pm 1.16^{\mathrm{c}}$ & $35.62 \pm 1.53^{\mathrm{b}}$ & $55.51 \pm 2.66^{\mathrm{a}}$ \\
Reducing power (OD) & $0.09 \pm 0.00^{\mathrm{d}}$ & $0.27 \pm 0.00^{\mathrm{c}}$ & $0.41 \pm 0.00^{\mathrm{b}}$ & $0.58 \pm 0.03^{\mathrm{a}}$ \\
\hline
\end{tabular}

${ }^{1)}$ Data were the mean $\pm \mathrm{SD}$ of triplicate experiments.

2)a-d Means with the same superscript within the same column are not significantly different at $\mathrm{p}<0.05$.

${ }^{3)} \mathrm{ND}$, not detected. 
여 제조한 죽에서는 2.69-55.51\%의 ABTS 라디칼 소거능을 보였다. 환원력도 아로니아 분말 첨가량에 비례하여 증가하 였다. 대조군에서는 0.09 의 흡광도를 나타냈고, 아로니아 첨 가량이 3-9\%까지 증가함에 따라 $720 \mathrm{~nm}$ 에서의 흡광도 값이 0.27-0.58까지 증가하는 것을 확인하였다. 선행연구에서도 아로니아를 첨가하여 제조한 스펀지케이크, 설기떡, 쿠키, 머 핀 등에서도 아로니아 첨가량에 비례하여 항산화 효능이 높 아짐을 확인하였다(Hwang과 Hwang, 2015; Jang 등, 2018; Lee와 Choi, 2016; Park과 Chung, 2014). Zhao 등(2014)은 식품에 함유된 폴리페놀과 플라보노이드 함량에 비례하여 항 산화 활성이 증가한다고 보고하여 본 연구결과와 유사한 결 과를 나타냈다. 아로니아 분말 함량에 비례하여 총페놀화합 물의 함량 및 항산화 활성은 증가하지만, 예비관능 평가 결 과, 아로니아 특유의 떫은맛과 죽의 점도 등을 고려하여 아로 니아 분말 함량은 죽 재료 전체 중량 비율의 $9 \%$ 를 넘지 않는 것이 죽의 품질 유지에 좋을 것으로 사료된다.

\section{요 약}

본 연구에서는 아로니아 분말 함량을 달리하여 쌀죽을 제 조하고 이화학적 품질 특성, 기능성 성분의 함량 및 항산화 활성을 측정하여 아로니아 분말 첨가 죽의 최적 배합비를 선 정하고 제품화 가능성을 탐색하였다. 죽의 수분함량은 80.41$80.84 \%$ 로 대조군과 아로니아 분말을 3-9\%까지 첨가하여 제 조한 죽에서 유의적인 차이가 관찰되지 않았다. 조회분은 대 조군과 아로니아 분말 3\% 및 $6 \%$ 첨가군에서는 차이가 없었 고, 아로니아 분말 $9 \%$ 첨가군에서는 높은 함량을 보였고, 조 단백질 함량은 아로니아 분말을 첨가하지 않은 대조군에 비 해 아로니아 분말 첨가군에서 높게 나타났으나, 분말 함량에 따른 차이는 없었다. 죽의 당도는 아로니아 분말 $9 \%$ 첨가군 에서 가장 높았고, $\mathrm{pH}$ 는 아로니아 함량이 증가함에 따라 감소 하는 경향을 보였다. 색도의 경우, 아로니아 분말 첨가량에 비 례하여 $\mathrm{L}^{*}$ 값과 $\mathrm{b}$ *값은 감소하였고, $\mathrm{a}$ *값은 증가하였다. 총폴 리페놀, 총플라보노이드 및 총안토시아닌 함량은 대조군에 비 해 아로니아 분말 첨가량이 증가할수록 높게 나타났다. 또한 $\mathrm{DPPH}$ 및 $\mathrm{ABTS}$ 라디칼 소거능과 환원력으로 측정한 항산화 활성도 아로니아 분말 함량이 증가할수록 높은 값을 나타났 다. 다만, 아로니아 특유의 떫은맛과 죽의 점도 등을 고려할 때 아로니아 분말 함량은 죽 재료 전체 중량 비율의 $9 \%$ 를 넘 지 않는 것이 죽의 품질 유지에 적합할 것으로 사료된다.

\section{Conflict of interests}

The authors declare no potential conflict of interest.

\section{ORCID}

Eun-Sun Hwang https://orcid.org/0000-0001-6920-3330

\section{References}

AOAC. Official Methods of Analysis of AOAC International. 16th ed, Association of Official Analytical Chemists, Washington DC, USA, p 1-26 (1995)

Banjari I, Misir A, Savikin K, Jokic S, Molnar M, De Zoysa HKS, Waisundara VY. Antidiabetic effects of Aronia melanocarpa and its other therapeutic properties. Front Nutr, 4, 53 (2017)

Bolling BW, Taheri R, Pei R, Kranz S, Yu M, Durocher $\mathrm{SN}$, Brand MH. Harvest date affects aronia juice polyphenols, sugars, and antioxidant activity, but not anthocyanin stability. Food Chem, 187, 189-196 (2015)

Cheung LM, Cheung PCK, Ooi VEC. Antioxidant activity and total phenolics of edible mushroom extracts. Food Chem, 81, 249-255 (2003)

D’Alessandro LG, Vauchel P, Przybylski R, Chataigne G, Nikov I, Dimitrov K. Integrated process extractionadsorption for selective recovery of antioxidant phenolics from Aronia melanocarpa berries. Sep Purif Technol, 120, 92-101 (2013)

Denev PN, Kratchanov CG, Ciz M, Lojek A, Kratchanova MG. Bioavailability and antioxidant activity of black chokeberry (Aronia melanocarpa) polyphenols: In vitro and in vivo evidences and possible mechanisms of action: A review. Compr Rev Food Sci Food Saf, 11, 471-489 (2012)

Gajic D, Saksida T, Koprivica I, Vujicic M, Despotovic S, Savikin K, Jankovic T, Stojanovic I. Chokeberry (Aronia melanocarpa) fruit extract modulates immune response in vivo and in vitro. J Funct Foods, 66, 103836 (2020)

Gim SW, Chae KS, Lee SJ, Kim KD, Moon JH, Kwon JW. Main constituents and bioactivities of different parts of aronia (Aronia melanocarpa). Korean J Food Sci Technol, 52, 226-236 (2020)

Hwang YR, Hwang ES. Quality characteristics and antioxidant activity of Sulgidduk prepared by addition of aronia powder (Aronia melanocarpa). Korean J Food Sci Technol, 47, 452-459 (2015)

Hwang ES, Tai ND. Quality characteristics and antioxidant 
activities of aronia jam replacing sucrose with different sugar substances. Korean J Food Nutr, 27, 888-896 (2014)

Hwang ES, Tai ND. Effects of different growing regions on quality characteristics, bioactive compound contents, and antioxidant activity of aronia (Aronia melanocarpa) in Korea. Prev Nutr Food Sci, 21, 255-262 (2016)

Jang NH, Roh HS, Kang ST. Quality characteristics of sponge cake made with aronia powder. Korean J Food Sci Technol, 50, 69-75 (2018)

Jeon JA, Choi JS, Jung EH, Kim CW, Bae EJ, Jeong ST. The quality characteristics of aronia by cultivation region. Korean J Food Preserv, 25, 804-810 (2018)

Jung HB, Kwon RW, Kong CS, Kim JG. Processing and quality characteristics of canned shrimp Marsupenaeus japonicus porridge added young ginseng Panax ginseng. JFMSE, 32, 499-510 (2020)

Kim MJ, Kim AJ. Quality characteristics of functional Nokdujuk prepared with optimum mixing ratio of mulberry leaf and fruit powder by response surface method. Korean J Food Sci Technol, 49, 699-709 (2017)

Kim YJ, Kim MJ, Kim HB, Lim JD, Kim AJ. Processing of functional porridge with optimal mixture ratio of mulberry leaf powder and mulberry fruit powder. J Korean Soc Food Sci Nutr, 46, 1081-1090 (2017)

Kim JS, Kwak EJ. Quality characteristics of gruel with added yam. Korean J Food Culture, 26, 184-189 (2011)

Kim GY, Lee CJ, Park HW. A comparative study on the literature of the cooking product of grain (rice, gruel) in Imwonshibyukji (I). J East Asian Soc Dietary Life, 8, 360-378 (1998)

Kim JN, Shin WS. Physical and sensory properties of chiffon cake made with rice flour. Korean J Food Sci Technol, 41, 69-76 (2009)

Ko JY, Song SB, Choe ME, Woo KS, Choi JM, Kwak DY, Kim KY, Jung TW, Ko JC, Oh IS. Quality characteristics and antioxidant activities of powdery instant porridge by characteristics of endosperm of foxtail millet. Korean J Food Nutr, 29, 465-473 (2016)

Lee JH, Choi JE. Quality characteristics and antioxidant activities of cookies supplemented with aronia powder. J Korean Soc Food Sci Nutr, 45, 1071-1076 (2016)

Lee GC, Kim JE, Kim SJ. Quality characteristics of Tarakjuk (milk-rice porridge) with different roasting conditions during refrigerated storage. Korean $\mathrm{J}$ Food Cookery Sci, 20, 342-351 (2004)

Lee JM, Durst RW, Wrolstad RE. Determination of total monomeric anthocyanin pigment content of fruit juices, beverages, natural colorants, and wines by the $\mathrm{pH}$ differential method: Collaborative study. J AOAC Int, 88, 1269-1278 (2005)

Lee SM. Quality characteristics of gruel added with ramie leaves. Korean J Culi Res, 19, 76-86 (2013)

Lee JE, Suh MH, Lee HG, Yang CB. Characteristics of Job's tear gruel by various mixing ratio, particle size and soaking time of Job's tear and rice flour. Korean J Food Cookery Sci, 18, 193-199 (2002)

Oyaizu M. Studies on product of browning reaction: Antioxidative activities of products of browning reaction prepared from glucosamine. Jap J Nutri, 44, 307-315 (1986)

Park HJ, Chung HJ. Influence of the addition of aronia powder on the quality and antioxidant activity of muffins. Korean J Food Preserv, 21, 668-675 (2014)

Re R, Pellegrini N, Proteggente A, Pannala A, Yang M, Rice-Evans C. Antioxidant activity applying an improved ABTS radical cation decolorization assay. Free Radical Biol Med, 26, 1231-1237 (1999)

Shim YE, Kum JS, Ahn YS, Park JD, Choi H, Seo DH, Lee BH. Effect of additives on physicochemical properties of gruels during storage. Korean J Food Sci Technol, 52, 162-166 (2020)

Sidor A, Drozdzynska A, Gramza-Michalowska A. Black chokeberry (Aronia melanocarpa) and its products as potential health-promoting factors-An overview. Trends Food Sci Technol, 89, 45-60 (2019)

Sim EY, Lee JY, Cho JH, Yoon MR, Kwak JE, Kim NG, Jeon YH, Lee CK, Lee JS, Hong HC. Quality characteristics of porridge made from different Korean rice varieties including high yield tongil-type rice. Korean $\mathrm{J}$ Food Preserv, 25, 651-658 (2018)

Snebergrova J, Cizkova H, Neradova E, Kapci B, Rajchl A, Voldrich M. Variability of characterisitic components of aronia. Czech J Food Sci, 32, 25-30 (2014)

Tsuda T. Dietary anthocyanin-rich plants: Biochemical basis and recent progress in health benefits studies. Mol Nutr Food Res, 56, 159-170 (2012)

$\mathrm{Wu}$ XL, Gu LW, Prior RL, McKay S. Characterization of 
anthocyanins and proanthocyanidins in some cultivars of Ribes, Aronia, and Sambucus and their antioxidant capacity. J Agric Food Chem, 52, 7846-7856 (2004) Yamane T, Kozuka M, Wada-Yoneta M, Sakamoto T, Nakagaki T, Nakano Y, Ohkubo I. Aronia juice suppresses the elevation of postprandial blood glucose levels in adult healthy Japanese. Clin Nutr Exp, 12, 20-26
(2017)

Yoon SJ, Hawer WD. A study on calorie and proximate components of traditional Korea gruel. J Korean Soc Food Sci Nutr, 37, 879-885 (2008)

Zhao Y, Du SK, Wang $\mathrm{H}$, Cai M. In vitro antioxidant activity of extracts from common legumes. Food Chem, 152, 462-466 (2014) 